\title{
Isolation and characterization of different bacterial agents from cray- fish (Astacus leptodactylus) of Aras reservoir, Iran
}

\author{
MY Yahyazadeh ${ }^{1}$, M Seidgar ${ }^{1}$ and S Shiri $^{1}$ \\ ${ }^{1}$ National Artemia Research Center, Iranian Fisheries Science Research Institute, Agricultural Research Educa- \\ tion and Extension Organization, Urmieh, Iran
}

Recived: June 2015

\begin{abstract}
Freshwater crayfish (Astacus leptodactylus) is an important economic fisheries resource of Aras reservoir, Iran. The infection of freshwater crayfish by gram negative and gram positive bacteria are common in natural and cultural environments. These bacteria are considered as secondary disease agents or opportunities. This study was conducted to investigate infestation condition on freshwater crayfish regarding the bacterial agents by culturing from haemolymph in aseptic condition on Blood Agar, Trypton Soya Agar (TSA) and Cytophaga Agar and was performed by biochemical tests. In this study Aeromonas hydrophila, Staphylococcus aureus, Micrococcus luteus and Flavobacterium johnsoniae were isolated and determined. According to the results which was performed for first time on Aras reservoir freshwater crayfish, the percentage of crayfish which carried the bacteria in haemolymph were variable (20.0-58.5\%). Also, the gram negative bacteria particularly Aeromonas hydrophila were dominant among the bacterial isolates from crayfish.
\end{abstract}

Keywords: bacterial infestation, Astacus leptodactylus, Aras reservoir, West Azarbaijan, Iran

\section{Introduction}

Freshwater crayfish (Astacus leptodactylus) of Aras

Correspondence M.Y. Yahyazadeh, National Artemia Research Center, Iranian Fisheries Science Research Institute, Agricultural Research Education and Extension Organization, Urmieh, Iran (e-mail: Yahyazadeh22002@yahoo.com)
Accepted: November 2015

reservoir is considered as one of the important economic aquatic animal resources of Iran. It provides a luxury and delicious but expensive meal in most countries. Such as other aquatic animals, A. leptodactylus is treated with a variety of biotic and abiotic factors (Unestam 1973). Also, harmful biotic factors to A. leptodactylus are classified as viruses, fungi, bacteria, rickettsia like organisms, protozoa and metazoan. Among these, Fungi (specially, Aphanomyces astasi which cause plaque) and viruses are the most harmful groups. In spite of long-term research on A. leptodactylus pathogens and other symbionts and or commensals, the pathology as well as geographic distribution has remained unclear (Vogt 1999). Bacteria are usually secondary or opportunistic pathogens, however some strains cause disease when host exposed to unsuitable environmental and biological condition such as crowding, inadequate nutrition and water pollution. Both gram negative and gram positive bacteria with or without clinical signs have been isolated from haemolymph of A. leptodactylus from natural habitat or cultural ponds. Pseudomonas sp., Aeromonas sp., Acinetobacter sp., Falvobacterium sp. and Vibrio sp. have been reported, as well as gram positive bacteria including micrococcus sp., Staphylococcus sp., Bacillus sp. (Scott \& Thune 1986; Fowler \& Desmarchelier, 1995; Webster 1995; Edgerton, Owens, Harris, Thomas \& Wingfield 1995). Rod shaped gram negative bacteria were prevalent in freshwater crayfish. In Astacus astacus, Cherax quadricarinatus, and C. albidusdestractor, $50 \%, 35 \%$ and $77 \%$ of observed bacteria were gram negative rod bacteria, respectively (Wong, Fowler \& Desmarchelier 1995; Madetoja \& Jussila 1996). Bacterial infection in freshwater crayfish can occur with septicemia or 
without any clinical sign. The latter does not show clinical signs or even pathologic injuries and detection is based on sampling from haemolymph and culture in bacterial culture media. The etiology and pathologic importance of the ones without any clinical sign is unclear and have a prevalence between 41 to $100 \%$ (Scott \& Thune 1986; Webster 1995; Wong, Fowler \& Desmarchelier 1995; Medetoja \& Jussila 1996). The major bacterial diseases reported in freshwater crayfish included bacteraemia, rickettsiosis, enteric infection, shell disease, eye necrosis syndrome and gill disease. Clinical signs of bacterial septicemia in freshwater crayfish are included lethargy, decrease in response to stimuli, decrease in muscle tonicity, muscle hardness, bacteriemia, small nodules or granoloma and haemocyte gathering due to defense reaction against bacteria, side standing and histopathologically gathering of haemocytic granules in heart, gills, hepatopancreas, antennal glands, abdomen muscles and connective tissue (Evans, Fan \& Finn 1992; Edgerton, Owens, Harris, Thomas \& Wingfield 1995). The aim of present study is to determine the isolated bacterial agents from freshwater crayfish (Astacus leptodactylus) of Aras reservoir, Iran.

\section{Materials and Methods}

During the year 2010, 70 juveniles and adult $A$. leptodactylus samples with different length and weight captured from Aras reservoir with conical traps, randomly. Also some physicochemical water parameters such as temperature, dissolved oxygen, $\mathrm{pH}$, total hardness and E.C. of Aras reservoir water were determined. All live samples were transported to laboratory and maintained in plastic vans with aeration for microbial studies. Haemolymph of $A$. leptodactylus samples were inoculated to bacterial culture media. Antenna or 5 th thoracopods were disinfected with 70\% alcohol and sliced and 1-2 drop of infiltrated haemolymph was cultured on blood agar, TSA and cytophaga agar mediums linearly under sterile condition. Cultured mediums were incubated in $22-25^{\circ} \mathrm{C}$ for $36-72 \mathrm{~h}$ and controlled for bacterial growth daily and primary identification was carried on gram staining of prepared slides. Then, grown bacteria were purified with secondary cultures and finally bacteria were identified based on biochemical and sugar fermentation tests.

\section{Results}

\section{Biometrical characteristics}

Biometrical characteristics of 70 adult and juvenile A. leptodactylus samples from Aras reservoir during 2010, revealed that the mean weight of males and females of samples were $31.39 \pm 12.21$ and $28.97 \pm 11.07 \mathrm{~g}$ and the mean length of them were $82.9 \pm 11.67$ and $103.6 \pm 10.56 \mathrm{~mm}$, respectively (Table 1).

\section{Physicochemical water parameters}

Some physicochemical water parameters of Aras reservoir were summarized in Table 2. The range of temperature, dissolved oxygen, $\mathrm{pH}$, total hardness and E.C of water were fluctuated in the range of 9.3$23.9{ }^{\circ} \mathrm{C}, 9.4-14 \mathrm{mgL}-1,7.4-8.96,284-580 \mathrm{mgL}-$ 1 and $247-1560 \mu \mathrm{mos} / \mathrm{cm}$, respectively.

\section{Bacteriological examinations}

The results showed that Aeromonas hydrophila, Staphylococcus aureus, Micrococcus luteus and Flavobacterium johnsonae were determined (Fig. 1) that the percent of infested Astacus leptodactylus varied between 20.0- 58.5\% which gram negative bacteria especially Aeromonas hydrophila was prevalent (Table 3). Also, some biochemical characters of isolated bacteria were summarized in Table 4 .

\section{Discussion}

Bacterial infestation in freshwater crayfish is common and usually considered as a secondary and opportunistic factor. In any case, different species of both gram negative and gram positive bacteria were identified and isolated from haemolymph of apparently healthy and without any clinical signs freshwater crayfish. The most common isolated bacteria were included Aeromonas spp., Pseudomonas spp., Acinitobacter spp., Flavobacterium spp., Vibrio spp., Citrobacteria spp., Staphylococcus spp., Microcuccus spp. and Bacillus spp., that ethi- 
Iranian Journal of Aquatic Animal Health

Table 1 Biometrical characteristics of Astacus leptodactylus samples.

\begin{tabular}{llllllllll}
\hline \multicolumn{2}{l}{ Astacus leptodactylus } & Weight $(\mathrm{g})$ & \multicolumn{7}{l}{ length $(\mathrm{mm})$} \\
\hline Sex & Number & Maximum & Minimum & Mean & SD & Maximum & Minimum & Mean & SD \\
Male & 45 & 118 & 4 & 31.39 & 12.21 & 155 & 60 & 82.9 & 11.67 \\
Female & 25 & 78 & 7 & 28.97 & 11.07 & 150 & 75 & 103.6 & 10.56 \\
\hline
\end{tabular}

Table 2 Some physicochemical water factors of dam reservoir.

\begin{tabular}{llllll}
\hline Number & Water Factors & Spring & Summer & Autumn & Winter \\
\hline 1 & Temperature ${ }^{\circ} \mathrm{C}$ & 19.4 & 23.9 & 14.0 & 9.3 \\
2 & Dissolved .Oxygen ( mg L-1) & 9.4 & 9.8 & 10.3 & 14.0 \\
3 & Ph & 7.4 & 8.2 & 8.2 & 8.9 \\
4 & Total Hardness ( mg L-1) & 286 & 284 & 580 & 424 \\
5 & E.C. $(\mu \mathrm{mos} / \mathrm{cm})$ & 750 & 247 & 280 & 1560 \\
\hline
\end{tabular}

Table 3 Prevalence of isolated bacteria from studied samples.

\begin{tabular}{lllllll}
\hline $\begin{array}{l}\text { Number of cul- } \\
\text { tured samples }\end{array}$ & $\begin{array}{l}\text { Bacterial growth } \\
(\%)\end{array}$ & Non-growth & $\begin{array}{l}\text { Aeromonas } \\
\text { hydrophila }\end{array}$ & $\begin{array}{l}\text { Staphylococcus } \\
\text { aureus }\end{array}$ & $\begin{array}{l}\text { Micrococcus } \\
\text { luteus }\end{array}$ & $\begin{array}{l}\text { Flavobacterium } \\
\text { johnsoniae }\end{array}$ \\
\hline 70 & $41(58.50 \%)$ & $29(41.50 \%)$ & $16(22.85 \%)$ & $12(17.14 \%)$ & $10(14.28 \%)$ & $3(4.28 \%)$ \\
\hline
\end{tabular}

Table 4 Some biochemical characters of isolated bacteria

\begin{tabular}{|c|c|c|c|c|c|c|c|c|c|c|c|c|c|c|c|}
\hline Bacteria & Gram & $\begin{array}{l}\text { Mo- } \\
\text { tility }\end{array}$ & $\begin{array}{l}\mathrm{Ni}- \\
\text { trate }\end{array}$ & $\begin{array}{l}\text { Gela- } \\
\text { tin }\end{array}$ & $\begin{array}{l}\mathrm{Ci}- \\
\text { trate }\end{array}$ & $\begin{array}{l}\text { Hae- } \\
\text { moly- } \\
\text { sis }\end{array}$ & $\mathrm{H} 2 \mathrm{~S}$ & $\begin{array}{l}\text { Oxi- } \\
\text { dase }\end{array}$ & $\begin{array}{l}\text { Cata- } \\
\text { lase }\end{array}$ & Indol & $\begin{array}{l}\text { Ure- } \\
\text { ase }\end{array}$ & $\mathrm{OF}^{*}$ & $\mathrm{MR}^{*}$ & VP* & $\mathrm{O} / 129 *$ \\
\hline $\begin{array}{l}\text { A. hy- } \\
\text { drophila }\end{array}$ & - & + & + & + & + & + & - & + & + & + & - & $\bar{F}$ & + & + & $\mathrm{R}^{*}$ \\
\hline M. luteus & + & - & - & + & - & + & - & + & + & - & - & $\mathrm{O}$ & - & - & \\
\hline S. aureus & + & - & + & + & + & + & - & - & + & + & & $\mathrm{F}$ & & + & \\
\hline $\begin{array}{l}\text { F. john- } \\
\text { soniae }\end{array}$ & - & - & + & + & - & - & - & + & + & -- & + & $\mathrm{F}$ & - & - & $\mathrm{S}^{*}$ \\
\hline
\end{tabular}

$\overline{\mathrm{O} / \mathrm{F}=\text { Oxidative } / \text { Fermentative. } \quad \mathrm{MR}=\text { Methyl Red. } \quad \mathrm{VP}=\text { Voges } \quad \text { Proskauer. }=* \mathrm{O} / 129=2 \text {, 4-diamino-6,7-diisopropylpteridine }}$ $\mathrm{R}=$ resistant. $\mathrm{S}=$ susceptible.

ology and pathologic importance of most of them is unknown. It has been reported that gram negative rod bacteria are prevalent in freshwater crayfish, as in Astacus astacus, Cherax quadricarinatus and C. albidusdestractor, 50,35 and $77 \%$ of observed bacteria were appertained to gram negative rod bacteria, respectively (Alderman \& Polglase 1988; Roy 1993; Webster 1995; Edgerton, Owens, Harris, Thomas \& Wingfield 1995). Similarly, in this study the identified bacteria were included gram negative bacteria of Aeromonas hydrophila and Flavobacterum johnsoniae and gram positive bacteria were included Staphylococcus aureus and Micrococcus luteus which isolated from haemolymph of apparently healthy and without clinical signs $A$. leptodactylus that among them A. hydrophila was preva- lent. Although the cause of bacterial infestation in apparently healthy freshwater crayfish is not clear, it seems that presence of bacteria in aquatic environments and environmental stress were the predominant factors for this condition. Thune (1994) and Medetoja \& Jussila (1996) showed the bacterial infestation incidence in healthy cultured freshwater crayfish and intensified the infestation in unsuitable condition such as high temperature, low dissolved oxygen and long-term maintenance on harmful condition.

Some workers have isolated a complex of bacterial species from haemolymph of freshwater crayfish and other crustaceans, especially spiny crab, Penaidae shrimps (Edgerton, Evans, Stephens \& Overstreet 2002). Also, some isolated bacteria were 

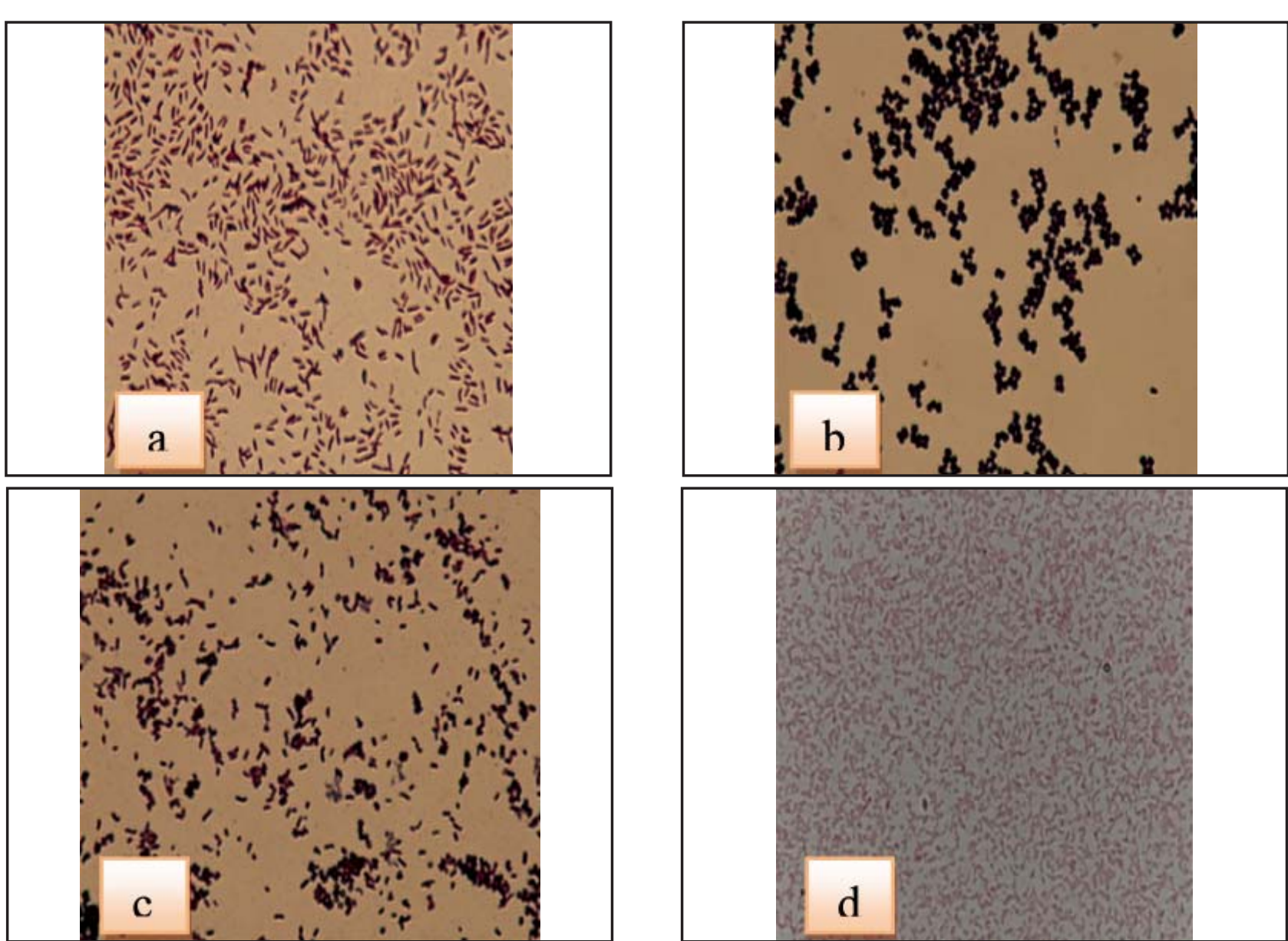

Figure 1 Isolated bacteria from crayfish samples from Aras Reservoir. a) Aeromonas hydrophila. b) Staphylococcus aureus. c) Micrococcus luteus. d) Flavobacterium johnsoniae.

reported as Flavobacterium spp. in freshwater crayfish with experimental infection (Scott \& Thune 1986; Wong, Fowler \& Desmarchelier 1995 ; Madetoja \& Jussila 1996; Edgerton, Evans, Stephens \& Overstreet 2002). Also, Micrococcus luteus and Staphylococcus spp. were reported from apparently healthy freshwater crayfish (Wong, Fowler \& Desmarchelier 1995). However, it's believed that the presence of bacterial agents in freshwater crayfish haemolymph necessarily is not the sign of disease and crustaceans can tolerate them without harmful effects while disease occurs at unsuitable and stress conditions (Jiravanichpaisal, Roos, Edsman, Liu \& Sderhall 2009). In certain cases mortality has reported in unsuitable cultured systems or natural environments from bacterial infections of freshwater crayfish with clinical signs and or even without clinical signs (Edgerton, Evans, Stephens \& Overstreet 2002; Quaglio, Morolli, Galuppi, Tampieri, Bonoli, Marcer, Rotundo \& Germinara 2006b). Aeromonas hydrophila is a ubiquitous gram negative bacterium of aquatic environment which can cause a large number of diseases in various aquatic animals, crustaceans and human being (Tulsidas, Ong \& Chan 2008). It can be the cause of morbidity and mortality in freshwater and marine fishes as a secondary agent with hemorrhagic septicemia. This bacterium is usually isolated from apparently healthy crayfish haemolymph or moribund fish and crustacean (Sung, Hwang \& Tasi 2000; Nielsen, Hoi, Schmidt, Qian, Shimata, Shen \& Larsen, 2001; Edgerton, Evans, Stephens \& Overstreet 2002; Jiravanichpasial, Roos, Edsman, Liu \& Sderhall 2009). As well as, it has a potential to create disease in freshwater crayfish especially at cultural and unsuitable environments (Quaglio, Morolli, Galuppi, Bonoli, Marcer, Nobile, De Luise \&Tampieri 2006a). Aeromonas hydrophila and some other bacteria were isolated from experimental re- infected Pasifastacus leniusculus, that the most mortality rate was due to 
A. hydrophila occurred at $22^{\circ} \mathrm{C}$ and $6 \mathrm{~h}$ after bacterial injection (Jirvanichpasial, Roos, Edsman, Liu \& Sderhall 2009). Therefore regarding the direct entrance of bacteria via environment, injury, gastrointestinal apparatus and haemolymph into body, crayfish containing bacterium can act as a carrier and reservoir of bacterium and change to pathogenic from opportunistic state at unsuitable environmental conditions, molting, stress and immunodeficiency and this can cause a serious threat for freshwater crayfish.

This study carried out on A. leptodactylus from Aras reservoir for the first time, revealed that interaction between parasitic, bacterial or commensal agents with host (A. leptodactylus) may depend on environmental condition, host immune defense and the intensity of invasion.

This interaction may collide regarding the presence of parasitic and bacterial agents in aquatic environments and the A. leptodactylus body surface, impact of human activities, including overfishing, industrial pollution and urban agriculture on aquatic ecosystems. However, recent studies by Mohsenpour Azari (2010) showed the euthrophic condition of Aras reservoir. On the other hand, unfavorable environmental condition, weakened crayfish, reduction of immune defenses, along with other factors, can cause viral, bacterial, parasitic and fungal diseases and damage to the aquatic resources such as crayfish A. leptodactylus.

Therefore, long- term monitoring together with good management of water resources can play an important role in decreasing of ongoing challenge.

\section{References}

Alderman D.J. \& Polglase J.L. (1988) Pathogens, parasites and commensals. In: Freshwater Crayfish-Biology, Management and Exploitation (ed. by D.M. Holdich, R.S. Lowery), pp. 167- 212. Croom Helm, London.

Edgerton B.F., Owens L., Harris L., Thomas A. \& Wingfield M. (1995) A health survey of farmed redclaw crayfish, Cherax quadricarinatus (von Martens), in tropical Australia. Freshwater Crayfish 10, 322- 338.
Edgerton B.F., Evans L.H., Stephens F.J. \& Overstreet R.M.(2002) Review of freshwater crayfish diseases and commensal organisms. Aquaculture Annual Review of Fish Diseases 206, 57-135.

Evans L.H., Fan A. \& Finn S. (1992) Health Survey of Western Australian Freshwater Crayfish. Curtin University of Technology, Perth.

Jiravanichpaisal P., Roos S., Edsman L., Liu H. \& Sderhall K.)2009(A highly virulent pathogen, Aeromonas hydrophila, from the freshwater crayfish Pacifastacus leniusculus. Journal of Invertebrate Pathology 101(1), 56-66.

Madetoja M. \& Jussila J. (1996) Gram negative bacteria in the hemolymph of noble crayfish Astacus astacus, in an intensive crayfish culture system. Nordic Journal Freshwater Research 72, 88- 90.

Mohsenpour Azari A., Yahyazadeh M.Y., Mohebbi F., Ahmadi R., Moniri Y. \& Shiri S. (2010) The impacts of environmental factors of Aras river and its reservoir on growth of A. leptodactilus. Project report, Iranian Artemia Research Center (In Persian).

Nielsen M.E., Hoi L., Schmidt A.S., Qian D., Shimata T., Shen J.Y. \& Larsen J.L. (2001) Is Aeromonas hydrophila the dominant motile Aeromonas species that cause disease outbreaks in aquaculture production in the Zhejiang Province of China. Diseases of aquatic Organisms 46 (1), 23-29.

Quaglio F., Morolli C., Galuppi R., Bonoli C., Marcer F., Nobile L., De Luise G., \&Tampieri M.P. (2006) Preliminary investigations of disease-causing organisms in the white-clawed crayfish Austropotamobius pallipes complex from streams of northern Italy. Bulletin Français de la Pêche et de la Pisciculture 380-381, 1271-1290.

Quaglio F., Morolli C., Galuppi R., Tampieri M.P., Bonoli C., Marcer F., Rotundo G. \& Germinara G.S. (2006) Sanitary-pathological examination of red swamp crayfish (Procambarus clarkii, Girard 1852) in the Reno Valley. Freshwater Crayfish 15, 1-10. 
Roy J.S.J. (1993) Effects of Aphanomyces astaci and Aeromonas hydrophilia on the Australian redclaw crayfish Cherax quadricarinatus. MSc Thesis, Auburn University, Auburn, Alabama.

Scott J.R. \& Thune R.L. (1986) Bacterial flora of hemolymph from red swamp crawfish, Procambarus clarkia (Girard), from commercial ponds. Aquaculture 58, 161165.

Sung H.H., Hwang S.F. \& Tasi F.M. (2000) Responses of giant freshwater prawn (Macrobrachium rosenbergii) to challenge by strains of Aeromonas spp. Journal of Invertebrate Pathology 76, 278-284.

Thune R. (1994) Diseases of Louisiana crayfish. In: Freshwater Crayfish Aquaculture in North America, Europe, and Australia, (ed. by V. Huner), pp. 117-156. Food Products Press, New York.

Tulsidas H., Ong Y.Y. \& Chan K.C. (2008) Aeromonas hydrophila bacteraemia and portal pyaemia. Singapore Medical Journal 49, 346-348.

Unestam T. (1973) Significance of diseases on freshwater crayfish. Freshwater Crayfish 1, 136-150.

Vogt G. (1999) Diseases of European freshwater crayfish, with particular emphasis on interspecific transmission of pathogens. In: Crayfish in Europe as Alien Species: How to Make the Best of a Bad Situation? (ed. by F. Gherardi, D.M. Holdich), pp. 87- 103. A.A. Balkema Publishers, Netherlands.

Webster N.S. (1995) The isolation and identification of bacterial flora from the red claw crayfish, Cherax quadrincarinatus. Honours Thesis, James Cook University of North Queensland, Townsville, Australia.

Wong F.Y.K., Fowler K. \& Desmarchelier P.M. (1995) Vibriosis due to Vibrio mimicus in Australian freshwater crayfish. Journal of Aquatic Animal Health 7, 284-291. 


\title{
آلودگى به عوامل باكتريايى در شاه ميكوى دراز آب شيرين سد ارس (Astacus leptodactylus)
}

\author{
مير يوسف يحيى زاده'"، مسعود صيدگر' '، صابر شيرى'

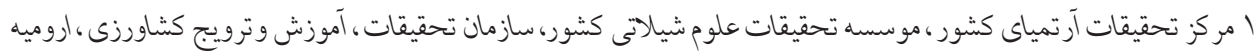

شاه ميخَوى دراز آب شيرين سد ارس از منابع آبزى مهمم اقتصادى كشور محسوب مىشود. آلودَّى به عوامل باكتريايى كَرم منفى وكَرم مثبت در

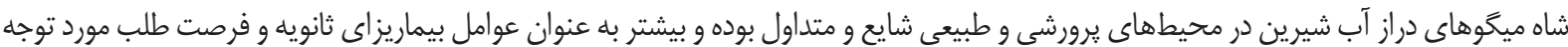

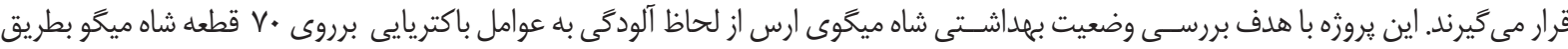

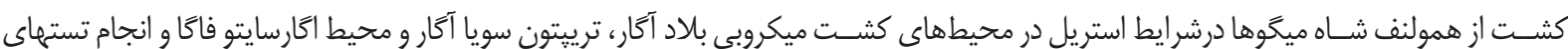
بيوشـيميايى صورت كَرفت و باكترى هـاى أئروموناس هيدروفيلا (Aeromonas hydrophila)، اسـتافيلوكو كوس اورئوس (Staphylococcus

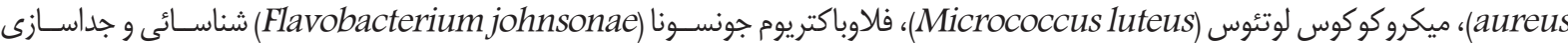
كَرديدند. براساس نتايج بدست آمده در اين يزوهش كه براى اولين بار بر روى شاه ميكوى دراز اب شيرين سد ارس صورت مى كيرد تعداد شاه ميكوهاى

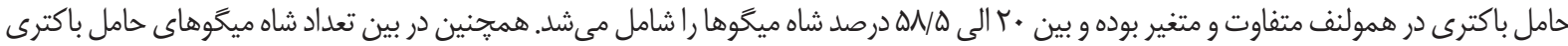

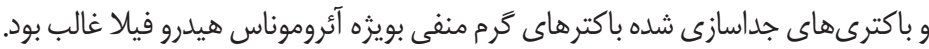
وازمهاى كليدى: شاه ميخو، آلود كى باكتريايى، سد ارس، آذربايجان غربى.

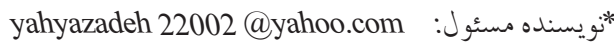

